\title{
Analisis 'Uqubah terhadap Muzakki yang Tidak Membayar Zakat Melalui Baitul Mal
}

\author{
Dr. Nurdin, M.Ag
}

${ }^{1}$ Dosen fakultas hukum dan Syariah Universitas Islam Negeri Arraniry

\begin{abstract}
Abstrak
Pengelolaan zakat di Aceh secara yuridis dilakukan oleh Pemerintah dan menjadi bagian dari Pendapatan Asli Daerah (PAD) baik pada Tingkat Provinsi maupun Pemerintah Kabupaten/Kota. Oleh karena itu perlu optimalisasi pengumpulan zakat. Pamerintah Aceh melalui Qanun tentang Baitul Mal telah melakukan upaya hukum untuk mengoptimalkan pembayaran zakat oleh umat Islam di Aceh yaitu dengan menetapkan sanksi bagi muzakki yang tidak menyerahkan zakat kepada Baitul Mal. Namun demikian 'uqubah tersebut masih terlalu ringan dan hamper tidak berjalan. Dalam penelitian ini, penulis ingin mengkaji masalah hukuman yang berlaku di Aceh terhadap muzakki yang enggan membayar zakat dan berdasarkan itu penulis menawarkan cara-cara baru kepada pemerintah Aceh agar pembayaran zakat optimal terlaksana. Karena itu penelitian ini adalah penelitian kepustakaan dengan pendekatan kualitatif. Berdasarkan hasil penelitian ditemukan bahwa, ringannya 'uqubah yang terdapat dalam qanun tentang Baitul Mal di Aceh adalah didasarkan pada pertimbangan bahwa, dalam Hukum Islam sanksi bagi muzakki yang tidak menunaikan zakat karena mengingkari kewajiban zakat adalah hukuman had (diperangi atau dibunuh). Sedangkan bagi muzakki yang enggan mengeluarkan zakat karena sikap kikir 'uqubahnya yaitu pengambilan harta zakat secara paksa dan disertai ta'zir berupa denda setengah dari hartanya dan kalau perlu dengan 'uqubah penjara.
\end{abstract}

Kata Kunci: Uqubat, Muzakki, Zakat, Baitul Mal, Aceh 


\section{PENDAHULUAN}

Hukum pidana adat mengatur tindakan yang melanggar perasaan keadilan dan kepatutan yang hidup di tengah masyarakat, sehinga menyebabkan terganggunya ketentraman serta keseimbangan masyarakat (Santoso, 1990:9).

Kebijakan pemerintah pusat menempatkan Provinsi Aceh sebagai daerah otonomi yang bersifat khusus didasarkan pada ketentuan Pasal 18 B ayat (1) UndangUndang Dasar Tahun 1945. Sebagai implementasi dari ketentuan pasal di atas, kepada Aceh diberikan hak untuk menjalankan syari'at Islam sebagaimana diatur dalam Undang-Undang Nomor 11 Tahun 2006 tentang Pemerintah Aceh. Pasal 125 Undang-Undang No 11 Tahun 2006 menegaskan bahwa :

(1) Syari'at Islam yang dilaksanakan di Aceh meliputi aqidah, syar'iyah dan akhlak.

(2) Syari'at Islam sebagaimana dimaksud pada ayat (1) meliputi ibadah, ahwal alsyakhshiyah (hukum keluarga), muamalah (hukum perdata), jinayah (hukum pidana), qadha' (peradilan), tarbiyah (pendidikan), dakwah, syiar, dan pembelaan Islam.
Pelaksanaan syariat Islam secara kaffah merupakan cita-cita dari segenap masyarakat Aceh agar terwujudnya tata kehidupan yang aman, tenteram, tertib, sejahtera dan adil dalam mencapai ridha Allah swt. Salah satu bentuk pemberlakuan syariat Islam di Aceh dalam bidang pengelolaan zakat (Amir, 2003: 37) yang menjadi kewenangan Pemerintah Daerah (Pemda). (Khairunnisak, 2017: 1)

Menurut bahasa, zakat berasal dari kata " zaka" yang artinya berkah, tumbuh, bersih dan baik. Sedangkan menurut bahasa Arab, arti dasar dari kata zakat, ditinjau dari segi bahasa adalah, suci, tumbuh, berkah dan terpuji. Semua arti dari zakat tersebut telah disebutkan dalam Al-Quran dan Hadits. Zakat dalam istilah fiqih berarti sejumlah harta tertentu yang diwajibkan Allah SWT diserahkan kepada orang-orang yang berhak.(Qardawi, 1999:34)

Al-Quran maupun sunnah telah menyinggung zakat harus dikelola oleh pemerintah, dalam Al-Qur-an pada surat At-Taubah ayat 103 Allah berfirman :

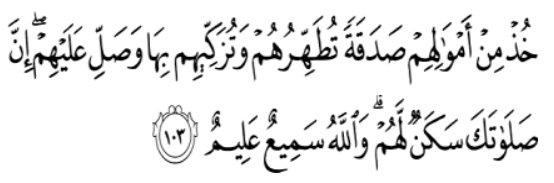

Artinya: "Ambillah zakat dari sebagian harta mereka, dengan zakat itu kamu membersihkan dan men- 
sucikan mereka dan mendo'alah untuk mereka. Sesungguhnya do'a kamu itu ketenteraman jiwa bagi mereka. Dan Allah Maha Mendengar lagi Maha Mengetahui".

Kata "khuwzh" yang tercantum dalam surat al-Taubah ayat 103 di atas, sebagai penegasan bahwa hanya pemerintah yang memiliki otoritas untuk mengambil dan mendayagunakan harta zakat. Allah swt. juga menyatakan dalam surat al-Taubah ayat 60 dengan kata " 'omilin" yang berbentuk jamak sebagai isyarat perlunya pengorganisasian dalam pengelolaan zakat. (Armiadi, 2015:1)

Pengelolaan zakat di Aceh secara yuridis dilakukan oleh Pemerintah dan menjadi bagian dari Pendapatan Asli Daerah (PAD) baik pada Tingkat Provinsi maupun Pemerintah Kabupaten/Kota. (Nurdin, 2017: 2) Ketentuan tersebut diatur dalam Undangundang Nomor 11 Tahun 2006 tentang Pemerintah Aceh, pada pasal 180. Sedangkan secara lebih khusus diatur dalam Qanun Aceh Nomor 10 Tahun 2018 tentang Baitul Mal.

Baitul Mal Propinsi dan Kabupaten/Kota diberikan kewenangan untuk mengelola zakat yang berasal dari masyarakat yang ada di Propinsi Aceh maupun Kabupaten/Kota baik dari unsur pedagang, pengusaha, petani, pekebun, PNS ataupun Pejabat dan Ka- ryawan yang beragama Islam. Demikian juga diberikan kewenangan untuk mengelola Zakat Mal yang berasal dari BUMN, BUMD, Badan Hukum, serta profesi lainnya. Pada Pasal 102 Qanun Aceh Nomor 10 Tahun 2018 menentukan:

(1) Setiap orang yang beragama Islam atau Badan Usaha yang dimiliki oleh orang Islam dan berdomisili dan/atau melakukan kegiatan usaha di Aceh yang memenuhi syarat sebagai Muzakki wajib menunaikan Zakat melalui Baitul Mal.

Qanun Baitul Mal Aceh bukan hanya mewajibkan muzakki untuk menunaikan zakatnya melalui baitul mal, tetapi juga mengatur tentang 'uqubat atau hukuman yang akan diterima oleh muzakki apabila tidak menunaikan zakatnya melaluui Baitul Mal. Ketentuan 'uqubat dalam Qanun Nomor 10 Tahun 2018, diatur pada Pasal 154, yang menentukan: Setiap orang Islam atau Badan yang melanggar ketentuan Pasal 102 dihukum karena melakukan jarimah ta'zir dengan 'Uqubat berupa :

a. denda satu kali nilai Zakat yang wajib dibayarkan;

b. kewajiban membayar seluruh biaya yang diperlukan sehubungan dengan audit khusus; dan

c. mengembalikan semua kerugian akibat perbuatannya. 
Ketentuan pasal 154 Qanun Baitul Mal mempunyai implikasi hukum yang luas, baik terhadap jumlah 'uqubah maupun terhadap muzakki yang tidak menunaikan zakat melalui baitul Mal. Zakat dalam konteks hukum Islam merupakan salah satu kewajiban bagi seluruh umat Muslim. Kedudukannya dalam peribadatan adalah sebagai salah satu dari rukun Islam. Oleh karena itu 'uqubah atau sanksi terhadap muzakki yang enggan membayar zakat berbeda dengan uqubah lainnya.

Muzakki yang tidak menunaikan ibadah zakat dapat dikenakan sanksi keras dan berganda, yaitu sanksi di dunia dan di akhirat karena penolakan membayar zakat telah melakukan kesalahan ganda pula, yaitu kesalahan terhadap Allah dan kepada orang-orang yang mempunyai hak dalam hartanya. Muzakki yang enggan mengeluarkan zakat bukan hanya diancam dengan hukuman materi. Akan tetapi pemerintah diberikan kewenangan menghukum secara fisik dan penjara, sesuai dengan kondisi dan situasi. Ketentuan demikian sesuai dengan kasus penolakan membayar zakat pada masa $\mathrm{Abu}$ Bakar. Abu Bakar dengan tegas bersikap dengan menegaskan: Wahai Umar, "Demi Allah, aku akan memerangi siapapun yang memisahkan shalat dengan zakat". (Haekal, 2013: 88)
Adapun terhadap muzakki yang tidak menunaikan zakat melalui baitul Mal juga mempunyai persoalan tersendiri mengingat zakat dalam sebagian masyarakat masih dikelola secara tradisional, ada zakat yang diserahkan kepada pembangunan mesjid, pembangunan tempat pengajian dan ada pula yang diserahkan secara langsung oleh Muzakki kepada Mustahik. (Zulhamdi, 2014:4)

Berdasarkan uraian di atas maka pembahasan ini akan menganalisis bagaimana 'Uqubat yang seharusnya ditetapkan Kepada Muzakki yang Tidak Menunaikan Zakat Melalui Baitul Mal Aceh.

\section{METODE PENELITIAN}

Penelitian ini merupakan penelitian kepustakaan (library research), yaitu penelitian yang dilakukan dengan meneliti data sekunder. Pendekatan yang digunakan adalah pendekatan perundang-undangan (statue approach) yakni pendekatan dengan menggunakan legislasi dan Konsepsi. Referensi utama dalam membahas 'uqubah terhadap muzakki ini menggunakan Al-Qur-an dan Hadits serta peraturan perundang-undangan yaitu Undang-Undang Nomor 11 Tahun 2006 dan Qanun Aceh Nomor 8 Tahun 2018 tentang Baitul Mal serta dengan mengutip pendapat para ulama yang berkaitan dengan 
'uqubah bagi pelanggar zakat. Analisis data dilakukan melalui preskriptif analisis.

\section{HASIL PENELITIAN DAN PEMBAHASAN}

3.1 'Uqubah Terhadap Muzakki Yang Tidak membayar Zakat Menurut Qanun Aceh Nomor 10 Tahun 2018

Berdasarkan Qanun Nomor 10 Tahun 2018, Baitul Mal Propinsi dan Kabupaten/Kota diberikan kewenangan untuk mengelola zakat yang berasal dari masyarakat yang ada di Propinsi Aceh maupun Kabupaten/Kota baik dari unsur pedagang, pengusaha, petani, pekebun, PNS ataupun Pejabat dan Karyawan yang beragama Islam. Demikian juga diberikan kewenangan untuk mengelola Zakat Mal yang berasal dari BUMN, BUMD, Badan Hukum, serta profesi lainnya. Pada Pasal 102 Qanun Aceh Nomor 10 Tahun 2018 menentukan: (1) Setiap orang yang beragama Islam atau Badan Usaha yang dimiliki oleh orang Islam dan berdomisili dan/atau melakukan kegiatan usaha di Aceh yang memenuhi syarat sebagai Muzakki wajib menunaikan Zakat melalui Baitul Mal.

Berdasarkan ketentuan Qanun Baitul Mal Aceh, bukan hanya mewajibkan muzakki untuk menunaikan zakatnya tetapi juga menga- tur tentang 'uqubat atau hukuman yang akan diterima oleh muzakki apabila tidak menunaikan zakatnya melaluui Baitul Mal. Ketentuan 'uqubat dalam Qanun Nomor 10 Tahun 2018, diatur pada Pasal 154, yang menentukan: Setiap orang Islam atau Badan yang melanggar ketentuan Pasal 102 dihukum karena melakukan jarimah ta'zir dengan 'Uqubat berupa :

a. denda satu kali nilai Zakat yang wajib dibayarkan;

b. kewajiban membayar seluruh biaya yang diperlukan sehubungan dengan audit khusus; dan

c. mengembalikan semua kerugian akibat perbuatannya.

Berdasarkan Ketentuan pasal 154 Qanun Baitul Mal, muzakki yang tidak menunaikan zakat melalui baitul Mal Aceh atau Kabupaten/Kota dikenakan 'uqubat, denda, kewajiban membayar seluruh biaya akibat audit khusus dan mengembalikan semua kerugian akibat perbuatannya. Penerapan ketentuan pidana terhadap muzakki yang tidak mau membayar zakat dimaksudkan supaya pendapatan daerah dari unsur zakat dapat diperoleh secara maksimal. Khusus untuk Pmerintah Aceh, zakat memiliki tempat khusus dalam pemerintahan, selain sebagai penunjang Pendapatan Asli Daerah (PAD), pengelolaan zakat di Aceh dilaku- 
kan oleh sebuah lembaga khusus bernama Baitul Mal.

Kebijakan menempatkan zakat sebagai bagian dari Pendapatan Asli Daerah di Aceh, diatur dalam Undang-Undang Nomor 11 Tahun 2006 pada Pasal 180 ayat (1) huruf d, menyebutkan: "Zakat merupakan salah satu sumber PAD Aceh dan PAD Kabupaten/Kota". Pasal 191 menyebutkan: "Zakat, harta wakaf dan harta agama dikelola oleh Baitul Mal Aceh dan Baitul Mal Kabupaten/Kota yang diatur dalam Qanun". Sebagai implementasi ketentuan tersebut, lahir Qanun Aceh Nomor 10 Tahun 2018 tentang Baitul Mal. Oleh karena itu, zakat bukan hanya kewajiban syariat semata, melainkan kewajiban yang telah ditetapkan oleh negara.

Baitul Mal merupakan lembaga resmi yang mengelola zakat, infaq dan sadaqah di Aceh. Lembaga ini memiliki peran penting dalam membantu masyarakat muslim untuk bangkit dari keterpurukan ekonomi, dan dengan memiliki mekanisme yang baik akan memudahkan manajemen pengelolaan dan penyaluran dana yang ada di Baitul Mal. Mekanisme yang dimaksudkan dalam penelitian ini adalah cara kerja lembaga zakat yaitu Baitul Mal Aceh terkait ditetapkannya zakat sebagai Pendapatan Asli Daerah (PAD), baik dari segi pengelolaannya maupun penyalurannya. Mekanisme ini juga diharapkan mampu mengikuti kebutuhan zaman namun tetap berlandaskan ketentuan syariat. (Khairunnisak: 14)

Pendapatan Asli Daerah (PAD) merupakan semua penerimaan daerah yang berasal dari sumber ekonomi asli daerah. Menurut Nurlan, PAD adalah pendapatan yang diperoleh daerah berdasarkan peraturan daerah sesuai dengan peraturan perundangundangan, dan hasilnya dimanfaatkan untuk penyelenggaraan tugas-tugas pemerintahan dan kegiatan pembangunan dalam rangka mengisi kemandirian otonomi daerah.( Darise, 2006: 3) Pendapatan Asli Daerah (PAD) merupakan semua penerimaan yang diperoleh daerah dari sumber-sumber dalam wilayahnya sendiri yang dipungut berdasarkan peraturan daerah sesuai dengan peraturan perundangundangan yang berlaku. (Halim, 2004: 96) Dengan demikian, maka Undang-undang Pemerintah Aceh dan Qanun Baitul Mal menjadi dasar bagi pelaksanaan zakat sebagai PAD di Provinsi Aceh.

\subsection{Analisis 'Uqubah Terhadap $\mathrm{Mu}$ - zakki Yang Tidak membayar Za- kat Kepada Baitul Mal Aceh}

Berdasarkan Pasal 154 Qanun Baitul Mal Aceh menentukan 'uqubah terhadap muzakki yang tidak mau membayar zakat melalui 
Baitul Mal Aceh maupun Kabupaten/Kota dengan ancaman denda satu kali nilai Zakat yang wajib dibayarkan; kewajiban membayar seluruh biaya yang diperlukan sehubungan dengan audit khusus; dan mengembalikan semua kerugian akibat perbuatannya. Ketentuan tersebut mempunyai implikasi hukum yang luas terhadap muzakki di Aceh.

Muzakki di Aceh umumnya tidak mengeluarkan zakatnya secara modern, diman, Zakat dalam sebagian masyarakat Aceh masih dikelola secara tradisional, ada zakat yang diserahkan kepada pembangunan mesjid, pembangunan tempat pengajian dan ada pula yang diserahkan secara langsung kepada mustahak. Sehingga dengan sistem seperti ini muzakki dapat memberikan zakatnya kepada mustahak yang diinginkan. Namun demikian apabila dikaitkan dengan ketentuan Pasal 154 Qanun Baitul Mal, maka kepada muzakki tersebut dikenakan 'uqubat karena tidak menyerahkan zakatnya kepada Baitul Mal.

Kriminalisasi terhadap muzakki yang tidak menyerahkan zakatnya kepada Baitul Mal, karena membagi sendiri zakatnya, harus diantisipasi secara yuridis karena merupakan pelanggaran terhadap hak warga Negara. Oleh karena itu perlu adanya norma hukum untuk melindungi muzakki yang secara tradisional membayar zakatnya sendiri dengan iktikad baik dalam rangka menjalankan perintah $\mathrm{Al}$ lah.

'Uqubah sebagaimana ditentukan dalam Pasal 154 Qanun Baitul Mal seharusnya diterapkan kepada Muzakki yang sama sekali tidak membayar zakat, karena Zakat dalam konteks hukum Islam merupakan salah satu kewajiban bagi seluruh umat Muslim. Namun demikian kadar atau ketentuan 'uqubah yang diatur dalam Pasal 154 di atas masih sangat rendah dibandingkan dengan kejahatan yang dilakukan oleh muzakki yang sama sekali tidak mau mengeluarkan zakat.

Rendahnya 'uqubah sebagaimana diatur dalam Qanun Baitul Mal, karena dalam Islam zakat merupakan salah satu rukun Islam dan menolak melaksanakan hukum Islam berarti telah mengingkari kewajiban sebagai muslim. Oleh karena itu status hukum orang yang mengingkari kewajiban dapat menyebabkan kekafiran. Muhammad Abu Zahra, mengemukakan bahwa status hukum orang yang meninggalkan zakat adalah: Apabila orang yang ingkar zakat tersebut seorang muslim dan menjadi penduduk negara Islam dan jalan untuk mengetahui tentang kewajiban zakat terbuka, maka tidak ada alasan baginya untuk tidak mengetahui. Para ulama mengatakan bahwa dia termasuk orang yang mur- 
tad. Sebab dalil wajibnya zakat jelas dan tegas disebutkan di dalam Al-quran dan Hadits.

Oleh karena itu, orang yang mengingkari kewajiban zakat berarti mendustakan kitab Allah dan Sunnah Rasul, barang siapa menolak menunaikan zakat sebagai salah satu kewajiban agama, maka ia termasuk muslim durhaka. Dia harus ditindak tegas dan dikenakan sanksi (ta'zir).( Zahra. 1999: 19-21) Muhyiddin AnNawawi, menegaskan kewajiban zakat adalah ajaran agama Allah ta'ala yang diketahui secara pasti. Sehingga, orang yang mengingkari kewajibannya sesungguhnya telah mendustakan Allah ta'ala dan mendustakan Rasulullah shallallahu 'alaihi wasallam, sehingga ia dihukumi kufur. (An-Nawawi, 2003: 331) Kewajiban zakat itu berdasarkan Kitab Allah, Sunnah dan Ijma". Siapa yang mengingkari kewajibannya, maka dia dihukum kafir. Jika mengingkarinya karena kebakhilan semata, maka hartanya dapat disita secara paksa. Adapun jumlah harta yang boleh disita adalah separohnya. (Qadir, 1998: 38)

Para ulama bersepakat (berijma') bahwa siapa yang menentang dan mengingkari kewajiban zakat, maka ia telah kafir dan murtad dari Islam. Karena ini adalah perkara ma'lum minad diini bid doruroh, yaitu sudah diketahui akan wajibnya. Ibnu Hajar berkata, ada- pun hukum asal zakat adalah wajib. Siapa yang menentang hukum zakat ini, ia kafir. Az- Zahaby, mengkategorikan orang yang tidak mau membayar zakat, tergolong pemikul dosa besar. Termasuk dalam kategori pembangkang zakat termasuk orang-orang yang sengaja dan mencari-cari alasan sehingga dia berusaha melepaskan dari jangkauan petugas zakat.

Orang yang enggan menunaikan zakat dalam keadaan meyakini wajibnya, ia adalah orang fasik dan akan mendapatkan siksa yang pedih di akhirat. Allah Ta'ala berfirman pada Surat At-Taubah ayat 34-35:

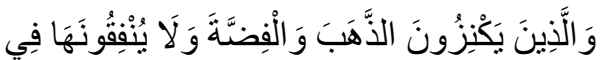

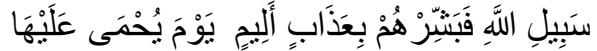

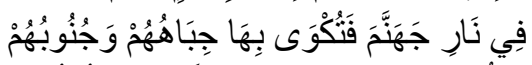

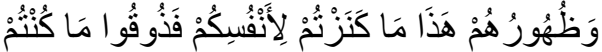

$$
\begin{aligned}
& \text { نَكَنْزُونَنَ }
\end{aligned}
$$

Artinya : "Dan orang-orang yang menyimpan emas dan perak dan tidak menafkahkannya pada jalan Allah, maka beritahukanlah kepada mereka, (bahwa mereka akan mendapat) siksa yang pedih, pada hari dipanaskan emas perak itu dalam neraka jahannam, lalu dibakar dengannya dahi mereka, lambung dan punggung mereka (lalu dikatakan) kepada mereka: "Inilah harta bendamu yang kamu simpan untuk dirimu sendiri, maka rasakanlah sekarang (akibat dari) apa yang kamu simpan itu." 
Muzakki yang tidak menunaikan zakat sama dengan memakan harta yang bathil, haram atau sama saja dengan korupsi, karena harta zakat adalah hak orang lain dan bukan lagi menjadi haknya walaupun harta itu memang ada di tangannya dan memang hasil dari usahanya sendiri. Ini penting untuk digaris bawahi, karena perbuatan ini tentu saja akan mengotori jiwa kita dan membuat doa tidak akan dikabulkan Allah karena ia telah memakai atau mengonsumsi harta yang haram. Itulah sebabnya, zakat sangat penting bagi penyucian jiwa. (Muttaqien, tt: 89)

'Uqubah terhadap muzakki yang tidak membayar zakat, secara duniawi yaitu pemerintah diperkenankan mengambil paksa zakat yang harus dibayarkan dan memberi hukuman pada pelaku agar jera. Muzakki yang enggan mengeluarkan zakat bukan hanya diancam dengan hukuman materi. Akan tetapi pemerintah diberikan kewenangan menghukum secara fisik dan penjara, sesuai dengan kondisi dan situasi. Ketentuan demikian sesuai dengan kasus penolakan membayar zakat pada masa Abu Bakar. Abu Bakar dengan tegas bersikap dengan menegaskan: Wahai Umar, "Demi Allah, aku akan memerangi siapapun yang memisahkan shalat dengan zakat".(Haekal, 2013: 88) Imam Al-
Qaffal menegaskan, jika pemilik harta tidak mau membayar zakat sebab bakhil, maka zakat diambil paksa darinya dan ia berhak dita'zir." (Bakar, 2004: 10)

Jarimah ta'zir merupakan salah satu bentuk 'uqubah dalam hukum Islam, secara bahasa ta'zīr berarti mencegah dan menolong. Adapun menurut istilah ahli fikih, ta'zīr adalah hukuman yang ukurannya dipasrahkan kepada hakim, baik disyariatkan berkenaan dengan hak Allah ataupun yang berkenaan dengan hak anak adam. Ta'zīr diartikan sebagai hukuman atas dosa yang tidak ada hukuman hadd atau kifaratnya. Berdasarkan makna ini, maka bentuk tindak pidana ta'zīr tidak disebutkan jumlahnya, juga tidak ditentukan apa hukumannya. Intinya, semua tindakan yang dianggap melanggar hak Allah dan hak menusia, maka hakim atau pemerintah diberi keluasan dalam menentukan apa dan bagaimana hukum dibebankan kepada pelaku.

Berdasarkan dari hak yang dilanggar, jarīmahta'zīr dibagi ke dalam dua bentuk. Pertama, menyinggung hak Allah. Kedua, menyinggung hak menusia. Dalam pembagian ini, maka dapat diketahui bahwa jarimah zakat masuk dalam jarimah ta'zīr yang menyinggung hak Allah sekaligus melanggar hak manusia, sebab tidak membayar zakar karena kikir ma- 
suk dalam kemasiatan (ma'șiyyah). Dilihat dari sifatnya, jarìmahta'zīr dibagi ke dalam tiga bentuk. Pertama, melakukan perbuatan maksiat. Kedua, melakukan kejahatan yang membahayakan kepentingan umum. Ketiga, melakukan pelanggaran.

Berdasarkan dasar hukumnya, jarīmah ta'zīr dibagi ke dalam tiga bentuk. Pertama, jarīmah ta'zīr yang berasal dari jarīmah hudūd atau qișāṣ, tetapi syaratsyaratnya tidak terpenuhi, atau dimungkinkan ada syubhat di dalamnya. Kedua, jarīmahta'zīr yang jenisnya disebutkan dalam nas syara', tetapi hukumannya belum ditetapkan, seperti riba, suap, atau mengurangi takaran timbangan. Ketiga, jarimah ta'zīr yang baik jenis maupun sanksinya belum dijelaskan dalam nas syara'. Orang yang meninggalkan shalat dan zakat termasuk dalam tindak pidana hudud yang diperselisihkan, maksudnya diperselisihkan adalah apakah termasuk bagian dari tindak pidana hudud, karena didalamnya terdapat had ataukah termasuk dalam kategori ta"zir. Orang yang meninggalkan shalat dan zakat di sini diartikan sebagai siapapun dari kaum muslimin yang tidak mengerjakan shalat lima waktu dan atau tidak membayar zakat karena melecehkan atau mengingkari. Hal yang demikian membuatnya menjadi kafir dan ia dibunuh karena had.( Faruk, 2009: 42)

Berdasarkan kriteria di atas, maka jarīmah muzakki yang tidak membayar zakat karena kikir masuk dalam jarìmah ta'zīr yang jenisnya disebutkan nas syara'. Hal ini dipahami dari makna umum Qur-an Surat At-Taubah ayat 3435 , yang mengancam orang yang menyembunyikan hartanya dengan cara dibakar dahi mereka, lambung dan punggung mereka pada hari Kiamat.

Penentuan jenis 'uqubat yang dapat dijatuhkan terhadapat orang-orang yang tidak mau mengeluarkan zakatnya, menurut golongan Syafi"iyah, "Barangsiapa yang wajib zakat, akan tetapi menolak untuk mengeluarkan, maka hendaknya diperhatikan: Apabila ia mengingkari kewajiban, maka sesungguhnya ia telah kufur, karena itu bunuhlah oleh sebab kekufurannya itu, sebagaimana harus dibunuhnya si murtad, karena kewajiban zakat itu suatu hal yang disyaratkan secara jelas dalam Islam. Barangsiapa yang ingkar akan kewajiban, berarti ia telah berbohong kepada Allah, berbohong kepada Rasul Nya, karenanya harus dihukum dengan sebab kekufuran itu. Dan jika tidak mau mengeluarkan karena kikir, maka zakat harus diambil juga daripadanya, dan ia harus diberi peringatan. Jika perlu dapat dihu- 
kum kurungan. (Qardawi, 2007:765) Golongan Hanafiyah, berpendapat bahwa orang-orang yang enggan mengeluarkan zakatnya harus diperiksa dan disumpah untuk membuktikan keterangannya. Jika ternyata mereka dusta maka zakatnya harus dipungut meskipun telah berlalu beberapa tahun dan diperhitungkan sebagaimana mestinya. Adapun golongan Malikiyah, berpendapat bahwa zakat dari orang-orang kaya harus dipungut secara paksa, dan dikenakan ta"zir, kalau perlu dikenakan hukum tahanan, jika mereka menentang. Dalam hal ini penguasa boleh mengambil sikap tegas kalau perlu menyita sebanyak yang harus dikeluarkan zakatnya.

Berdasarkan uraian di atas maka zakat merupakan salah satu rukun Islam, zakat tidak hanya mempunyai dimensi ibadah (kewajiban kepada Allah) tetapi juga berdimensi muamalah (kewajiban kepada mustahik). Maka kewajiban menunaikan zakat memiliki dua pertanggungjawaban sekaligus, baik kepada Allah SWT maupun kepada mustahik. Oleh karena itu tidak menunaikan zakat karena kikir merupakan pelanggaran terhadap hak Allah dan hak manusia, dan dalam hukum pidana Islam masuk dalam kategori hukuman ta"zir. Sehingga sudah semestinya jika ada muzakki yang enggan atau lalai menunaikan zakatnya disanksi dengan 'uqubah ta'zir secara maksimal berupa cambuk, memasukkan k dalam penjara dan merampas sebahagian dari hartanya, karena dalam harta muzakki yangn bersangkutan masih terdapat hak-hak para mustahik.

\section{KESIMPULAN}

Dasar pertimbangan rendahnya 'uqubah terhadap muzakki yang tidak membayar zakat dalam Qanun Baitul Mal, karena dalam Hukum Islam sanksi bagi muzakki yang tidak menunaikan zakat karena mengingkari kewajiban zakat adalah hukuman had (diperangi atau dibunuh). Sedangkan bagi muzakki yang enggan mengeluarkan zakat karena sikap kikir 'uqubahnya yaitu pengambilan harta zakat secara paksa dan disertai ta'zir berupa denda setengah dari hartanya dan kalau perlu dengan 'uqubah penjara. Diharapkan kepada Pemerintah Aceh agar merevisi ketentuan Qanun Baitul Mal terkait 'uqubah terhadap muzakki yang tidak membayar zakat melalui baitul Mal, karena masyarakat Aceh masih membayar zakat secara tradisional. Perlu memperberat 'uqubah terhadap muzakki yang kikir dalam membayar zakat. 


\section{DAFTAR PUSTAKA}

AKP Erpan Syahputra, Kepala Kepolisian Sektor Dewantara, Kabupaten Aceh Utara, wawancara tanggal 26 Juli 2018, di Gampong Keude Krueng Geukueh.

Ilyas, A, Keuchiek Gampong Keude Krueng Geukueh, Kecamatan Dewantara, Kabupaten Aceh Utara, wawancara pada tanggal 29 Juni 2018 di Gampong Keude Krueng Geukueh.

Dian, Guru SMAN 1 Dewantara, wawancara pada tanggal 20 Juli 2018 di Gampong Keude Krueng Geukueh.

Kamaruzzaman, T. Anggota Majelis Adat Aceh Kecamatan Dewantara, Kabupaten Aceh Utara, wawancara pada tanggal 13 Juli 2018 di Gampong Keude Krueng Geukueh, Kecamatan Dewantara, Kabupaten Aceh Utara.

Rusli, Tgk. M., I. Anggota Tuha PeutGampong Keude Krueng Geukueh, Kecamatan Dewantara Kabupaten Aceh Utara, wawancara pada tanggal 29 Juni 2018 di Gampong Keude Krueng Geukueh. Abubakar, Y. A., dan. Hasan, S. M. 2006, Perbuatan Pidana dan $\mathrm{Hu}$ kumannya Dalam Qanun Provinsi NAD (Propinsi Nanggroe Aceh Darussalam), Banda Aceh: Dinas Syariat Islam Provinsi NAD (Propinsi Nanggroe Aceh Darussalam).

Anwar, C. 1997. Hukum Adat Indonesia Meninjau Hukum Adat Minangkabau. Jakarta:Rineka Cipta.
Aswar, T. R. I 2004, "Lembagalembaga Adat dan Hukumnya", Training Hukum Adat dan Istiadat Bagi Anggota Polri dan Peutua Adat Se-Provinsi NAD, Banda Aceh, 26-30 Juli.

Dahlan, A. A., Ed.1996. Ensiklopedi Hukum Islam, Ikhtiar Jakarta: Baru Van Houve.

Ismail, B. 2008. Pedoman Peradilan Adat di Aceh. Banda Aceh: T.t.p.

Santoso, T. 1990, Pluralisme Hukum Pidana Indonesia, PT. Ersesco, Jakarta. 